\title{
Praise for the first edition
}

'A gripping tale of discovery and detection, at once accessible and scholarly.'

William Dalrymple

'A highly readable and very personal, not to say personable, account of both the project and the interpretation of the site.'

History Scotland

'This is the popular book of that (ten-year) project ... A true academic, Carver has the confidence to write fresh, clear, direct, prose.'

Current Archaeology

'Beautifully written and beautifully clear ... it is impossible to imagine a better example of complex and subtle ideas made comprehensible without distortion.'

Peter Davidson, University of Aberdeen 
Colum Cille, Colum who was, Colum who will be (Tiugraind Beccáin, in Clancy and Márkus 1995: 149) 


\title{
Portmahomack
}

\section{Monastery of the Picts}

\author{
SEEOND EDITION
}

\section{Martin Garver}

EDINBURGH

University Press 
Edinburgh University Press is one of the leading university presses in the UK. We publish academic books and journals in our selected subject areas across the humanities and social sciences, combining cutting-edge scholarship with high editorial and production values to produce academic works of lasting importance. For more information visit our website: www.edinburghuniversitypress.com

(C) Martin Carver, 2008, 2016

First edition published 2008

Edinburgh University Press Ltd

The Tun - Holyrood Road

12 (2f) Jackson's Entry

Edinburgh EH8 8PJ

Typeset in 11/15 Adobe Garamond by Servis Filmsetting Ltd, Stockport, Cheshire and printed and bound in Malta by Gutenberg Press

A CIP record for this book is available from the British Library

ISBN 9780748697670 (paperback)

ISBN 9780748699971 (webready PDF)

ISBN 9780748697687 (epub)

The right of Martin Carver to be identified as author of this work has been asserted in accordance with the Copyright, Designs and Patents Act 1988 and the Copyright and Related Rights Regulations 2003 (SI No. 2498).

All illustrations are copyright Martin Carver and University of York, unless otherwise stated.

Published with the support of the Edinburgh University Scholarly Publishing Initiatives Fund. 